\title{
Notes on the frog fauna of the Amazon Basin
}

\author{
W. Ronald Heyer (")
}

\begin{abstract}
The natural history of the frog fauna of the Amazon Basin is considered, based on data cbtained from four major collections. Population structures in both forest and open environments are compared. Associations of species pairs in open formations are studied. It is estimated that at least 100 species are present in the Amazon Basin. Five speciation models are proposed to explain the high diversity of species.
\end{abstract}

I have had the opportunity to participate in two expeditions to the western Amazon region. This report deals with the natural history observations made on these trips together with an ecological analysis of the collections from these trips and collections from two other expeditions. All natural history observations and analyses on frogs are included here, rather than fragment the information. Taxonomic matters will be discussed in another paper.

The four expeditions on which this report is based are summarized briefly as:

1) Porto Velho: Departamento de Zoologia da Secretaria da Agricultura (now Museu de Zoologia, Universidade de São Paulo (MZUSP) expedition to Porto Velho, Rondônia, Brasil, from 28 October to 6 November 1954. This collection is represented by 17 species and 4086 individuals.

2) Expedição Permanente da Amazônia (EPA), supported by MZUSP, Fundação de Amparo à Pesquisa do Estado de São Paulo and Museu Goeldi; in 1973 a collaborative venture with the Museum of Comparative Zoology, Harvard University (Russell A. Mittermeier), from 20 August to 5 December 1973 along major rivers from Belém to Leticia, Colombia. Russell Mittermeier purchased 8238 individuals of 40 species incidental to the main purpose of the expedition.
3) Joint MZUSP and Smithsonian (USNM) expedition on the rio Purus, Brasil, from 2 December 1974 to 19 January 1975. This collection contains 811 specimens of 58 species.

4) Joint EPA-MZUSP and USNM expedition on the rio Madeira, Brasil from 31 October to 19 December 1975. The collection is represented by 1232 specimens of 53 species

The itineraries of these trips will be described in the taxonomic paper where they are more appropriate.

\section{ECOLOGICAL GENERALIZATIONS}

Faunal - Habitat Associations: At any locality in the Amazon basin, two major types of habitats are evident: forest and open. Of course, neither is a clear cut category for they grade ints one another smoothly or abruptly, depending more or less on the human activity of the region. Open habitats have always been present, particularly at the edges of rivers. For all of the specimens collected by scientific personnel on the Madeira and Purus expeditions, the major habitat type was recorded for each specimen collecter Categories were either: (1) forest, (2) modified forest, such as selective logging or old second growth, and (3) open formations, such as river edges and human clearings. For purposes of analysis, any intermediate habitat, recorded in the field notes, was scored as the more forested category. The results of percent of individuals taken from each habitat type for the common species are presented in Table 1. The criterion used for common species in this case is 10 or more individuals (pooled localities), except for Adenomera hylaedactyla and Hyla boans for which calling specimens (not coilected) supplement the actual specimens in the col(*) - Division of Reptiles and Amphibians. National Museum of Natural History. Smlthsonian Institution.
Washington, D.C. (U.S.A.). 
lection. If the rather rigid guideline of $80 \%$ occurrence in a single category is used, all but 4 species can be categorized as forest associated species (9) or open formation associated species $(20)$. The four remaining species are primarily forest associated (Phyllobates pictus), primarily open formation associated (Hyla lanciformis and perviceps) or distributed in both forest and open formations (Sphaenorhynchus eurhostus). The association of most Amazonian frogs with one or the other major habitat type suggests that the species have evolved in either forests or open habitats, not both. Only in one case for those species tabled is the particular part of the breeding habitat for which the species is adapted found in both forests and open formations. This breeding habitat for Sphaenorhynchus curhostus is a vegetation covered pond, either grass or Pistia.

The numbers of forests and open habitat associated species (Table 1) are not an accurate reflection of the true percentages of forests and open habitat associated species in the Amazonian anuran fauna. The open formation associated species were better sampled, because most specimens were collected from breeding chorus aggregations in open habitat ponds. In contrast, most forest associated species were collected individually from transects taken through the forest. This forest cruising technique produces few specimens but yields a high diversity. The distributions (Table 1) indicate that even with few habitat data, habitat association is reasonably accurate. Including the species with fewer than 10 individuals collected, there are presumable 38 forest associated species, 33 open formation associated species, and 2 species associated with both habitat types. As discussed below, the 73 species collected on the Madeira and Purus expeditions do not represent the total diversity of the Hylaean anuran fauna. As the open formation fauna is easier to collect, I assume that most of the Hylaean species not collected on the expeditions will be forest associated species.

All diurnal frogs are forest floor leaf litter species. All open formation associated frogs are nocturnal species. Most forest litter frogs share the same type of nocturnal resting sites, i.e. leaves of herbaceous plants from 5 to 100 $\mathrm{cm}$ above the forest floor (Bufo typhonius, Dendrophryniscus minutus, both common Phyllobates, Physalaenus petersi). No Adenomera andreae were taken on leaves at night. Additional members of the forest litter fauna include Dendrobates, quinquevittatus, Phyllobates trivittatus, and perhaps Edalorhina and one species of Eleutherodactylus. An approximation is that the forest litter frog fauna comprises about one quarter of the entire forest associated frog fauna.

TABLE 1. Distribution of inaividuals (in percentages) of common species among major habitat types. $\mathbf{A}=$ forest, $\mathbf{B}=$ modified forest, $=$ open formation. Also see text.

\begin{tabular}{|c|c|c|c|}
\hline SPECIES & A & B & C \\
\hline Adenomera andreae ... & 97 & 1 & 1 \\
\hline A. hylaedactyla $\ldots \ldots \ldots \ldots \ldots$ & 0 & 0 & 100 \\
\hline Bufo granulosus $\ldots \ldots \ldots \ldots \ldots \ldots$ & 0 & 0 & 100 \\
\hline B. marinus $\ldots \ldots \ldots \ldots \ldots \ldots \ldots$ & 4 & 2 & 93 \\
\hline B. typhonius $\ldots \ldots \ldots \ldots \ldots \ldots$ & 89 & 9 & 2 \\
\hline Colostethus peruvianus $\ldots \ldots \ldots \ldots$ & 86 & 14 & 0 \\
\hline Dendrophryniscus minutus $\ldots .$. & 100 & 0 & 0 \\
\hline Hyla $\mathrm{sp} \quad \ldots \ldots \ldots \ldots \ldots \ldots \ldots \ldots \ldots \ldots \ldots \ldots \ldots \ldots$ & 100 & 0 & 0 \\
\hline H. boans $\ldots \ldots \ldots \ldots \ldots \ldots \ldots \ldots \ldots \ldots \ldots \ldots \ldots \ldots$ & 0 & 0 & 100 \\
\hline H. fasciata . & 84 & 4 & 11 \\
\hline H. garbei $\ldots \ldots \ldots \ldots \ldots \ldots \ldots \ldots$ & 83 & 17 & 0 \\
\hline H. granosa $\ldots \ldots \ldots$ & 8 & 0 & 92 \\
\hline H. lanciformis $\ldots \ldots \ldots \ldots \ldots \ldots$ & 26 & 6 & 68 \\
\hline H. leali & 0 & 3 & 97 \\
\hline H. leucophyllata ............... & 11 & 4 & 86 \\
\hline H. parviceps $\ldots \ldots \ldots \ldots \ldots \ldots \ldots$ & 11 & 11 & 78 \\
\hline H. punctata $\ldots \ldots \ldots \ldots \ldots \ldots$ & 0 & 0 & 100 \\
\hline H. raniceps $\ldots \ldots \ldots \ldots \ldots \ldots \ldots \ldots$ & 0 & 2 & 98 \\
\hline H. hodopepla $\ldots \ldots \ldots \ldots \ldots \ldots$ & 6 & 0 & 94 \\
\hline H. riveroi $\ldots \ldots \ldots \ldots \ldots \ldots \ldots$ & 0 & 0 & 100 \\
\hline H. rubra $\ldots \ldots \ldots \ldots \ldots \ldots \ldots \ldots \ldots$ & 1 & 2 & 97 \\
\hline H. triangulum $\ldots \ldots \ldots \ldots \ldots \ldots$ & 0 & 0 & 100 \\
\hline H. waldorfi $\ldots \ldots \ldots \ldots \ldots \ldots \ldots$ & 0 & 2 & 98 \\
\hline Leptodactylus bolivianus ........ & 12 & 2 & 86 \\
\hline L. fuscus $\ldots \ldots \ldots \ldots \ldots \ldots \ldots \ldots \ldots \ldots$ & 0 & 6 & 93 \\
\hline L. ocellatus $\ldots \ldots \ldots \ldots \ldots \ldots \ldots \ldots \ldots$ & 0 & 0 & 100 \\
\hline L. wagneri ...... & 13 & 5 & 81 \\
\hline Lysapsus limellus $\ldots \ldots \ldots \ldots \ldots$ & 0 & 0 & 100 \\
\hline Phrynohyas venulosa $\ldots \ldots \ldots \ldots$. & 0 & 0 & 100 \\
\hline Phyllobates femoralis ... & 91 & 9 & 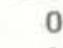 \\
\hline P. pictus $\ldots \ldots \ldots \ldots \ldots$ & 72 & 28 & 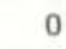 \\
\hline Physalaemus petersi $\ldots \ldots$. & 100 & 0 & 0 \\
\hline Sphaenorhynchus eurhostus & 45 & 0 & 55 \\
\hline
\end{tabular}


Species - Breeding Pond Associations: If species share the same types of breeding ponds, the species assemblage probably evolved in the same environment.

Few forest ponds were found with breeding frogs. In those few forest pona's with breeding choruses, the species present are in museum collections. Many forest ponds, which I assumed to be ideal for anuran reproduction lacked any breeding frogs. Forest ponds may be used either for a brief time or be largely unsatisfactory. Both possible explanations may result from fish predation. Many ponds which are isolated at the beginning of the rainy season may become flooded and connected with river backflows. It is these flooded areas where many river fish also breed and would likely feed on any anuran larvae in the water. Also, erythrinid fishes occur in isolated ponds and creeks (Vanzolini, pers. comm.) Thus, many of the seemingly ideal breeding pools contain carnivorous fishes. One evolutionary response by the forest associated pond breeders would be to reproduce as soon as ponds develop and to have a brief larvai life.

Data were recorded on species breeding in 28 open habitat ponds. The association between each species pair was evaluated by computing a coefficient of association, V , where

$$
V=\frac{a d-b c}{(m n r s) .5} .
$$

where the right hand terms come from a $2 \times 2$ contigency table set up as

\section{Species B}

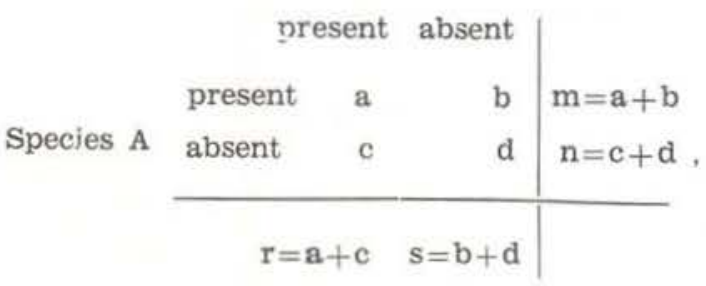

where $a, b, c, d$ are observed frequencies of species at breeding ponds (Pielou, 1969). V ranges from -1 (maximum negative association) to $t=1$ (maximum positive association). Zero is no association. For the analysis herein, association values were calculated for only those species recorded from 5 or more ponds. The results are presented in Table 2. Collins (1975) reported $V$ values for breeding associations in a series of ponds in Michigan. $\mathrm{He}$ found that after applying different statistical tests to the contigency table, $\mathrm{V}$ values greater than .3 represented statistically valid association. If that criterion is used on the species data in Table 2 , there are only 2 positive correlations: $S$. eurhostus $-H$. leucophyllata and $H$. leali $-L$. wagneri. This represents only $7 \%$ of the possible associations. In contrast, $25 \%$ of the temperate zone associations (Collins, 1975) were strongly positive. This difference suggests that the diversity of breeding ponds is lower and the available breeding period is shorter in Michigan than in Amazonia, a not unexpected explanation.

For the strongly negative associations $(<-3)$ in Table 2, there are 5 pairs, but only one of them, $\mathrm{H}$. leali $-\mathrm{H}$. riveroi, involves closely related members.

The absence of positive and presence of negative associations that characterize Table 2 are consistent with a recent study that concluded that interspecific competition is evolutionarily unimportant in tadpole communities (Heyer, in press). One would expect evolution to act on biological interactions only where positive associations between species occur.

TABLE 2. Associations between the common open habitat species. Number in parentheses is the number of breeding ponds where the species was present.

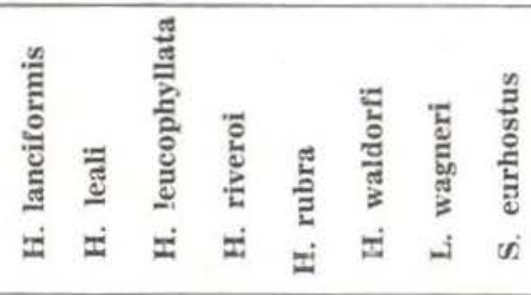

H. lanciformis

(7) $0.0-.16-.12 \quad .22-.03 \quad .04-.33$

H. leali

H. leucophyllata

$\begin{array}{lllllll}\text { (8) } & .13 & -.36 & 0.0 & .11 & .36 & 0.0\end{array}$

H. riveroi

H. rubra

H. waldorfi

L. wagneri

$\begin{array}{llllll}\text { (8) } & .19 & -.46 & -.07 & 0.0 & .55\end{array}$

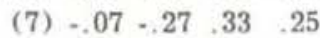

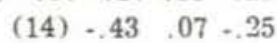

(5) $.15-.27$

(7) .25

S. eurhostus 
It appears thai the open formation fauna does not have a tightly integrated community structure, assuming breeding habitats are a reflection of the total community organization of frog communities.

River Edge Frogs: The following species are characteristic of the grassy river banks: Adenomera hylaedactyla, Bufo granulosus, Hyla boans, Hyla granosa, Hyla punctata, Hyla raniceps and Leptcdactylus fuscus. Of these, B. granulosus, $H$. punctata, $H$. raniceps, and L. fuscus also occur in other open habitats away from the river edge. Apparently only Hyla boans and Hyla granosa breed in the river itself. Of the several fish seine samples taken in the Madeira and Purus rivers tadpoles were taken only once. As argued elsewhere (Heyer, McDiarmid, and Weigmann, 1975), the river tadpoles must have specific adaptations that allow them to occur with predatory fish.

Adult Frog Food Resources: One of the perplexing problems in analyzing resource utilization by adult frogs is the difficulty of gathering information on non-breeding individuals. With such data, one might examine ecological problems in frogs in the same successful manner as West Indian anoles have been studied. One approach appears to be a potentially fruitful one, and very preliminary results are offered in hopes that others might find the problem worth further study. When one searches the forest by night with flashlight, one finds frogs sitting on leaves, as well as arthropods sitting on leaves. One night. M. Heyer and I attempted to capture every arthropod and frog from leaf surfaces within reach for a one hour time period. Two frogs and 159 arthropods (Table 3) were collected. Hyla lanciformis had a $5 \mathrm{~mm}$ beetle and 25 $\mathrm{mm}$ preying mantis in the gut and Hyla $s p$. had a $7 \mathrm{~mm}$ grasshopper in the gut. The food items did not appear to be the same species as found in the general collections, but were comprised of the same kinds of potential prey items we collected. We collected about 80 arthropods per hour per person - it superficially appears as though food resources are superabundant in the forest for frogs. No palatability. catchability or digestive studies have been done for tropical forest frogs, however, so it is not known what the true availability of food resources is for the frogs. A reasonable assumption at this point is that the nocturnal frogs seen on leaves at night in the forest are feeding on the arthropods also found on leaves at night (excluding diurnally active frogs which are resting on leaves at night, see above). Both the frogs and the arthropods are samplable resources.

TABLE 3. Arthropods collected on leaves at night in the forest.

\begin{tabular}{llr}
\hline Group & Size (classes) in mm & Number \\
\hline \multirow{3}{*}{ Spiders } & 2 & 5 \\
& $3-4$ & 2 \\
Cockroaches & 10 & 1 \\
Beetles & $6-10$ & 2 \\
& $12-27$ & 11 \\
Larval lepidopterans & $3-4$ & 4 \\
& $6-10$ & 16 \\
Homopterans & $10-12$ & 11 \\
Ants & $20-35$ & 2 \\
& 3 & 3 \\
Hemipterans & 3 & 2 \\
Dipterans & 11 & 1 \\
& 8 & 1 \\
& 5 & 1 \\
Moths & 13 & 2 \\
Walking sticks & 20 & 1 \\
Orthopterans & $7-10$ & 1 \\
& 16 & 7 \\
& $50-90$ & 1 \\
& $10-15$ & 3 \\
& $15-20$ & 3 \\
& $20-30$ & 33 \\
& $30-40$ & 24 \\
& $40-50$ & 10 \\
& & 8 \\
& & 4 \\
& &
\end{tabular}

\section{ANALYSIS OF RANDOM COLLECTIONS}

The collections from the Madeira and Purus expeditions are not truly random collections because sampling was biased against the most common species. For example, not all adult Bufo marinus seen were collected.

The Porto Velino - MZUSP and EPA -Mittermeier collections are as random in nature as frog collections can be. Ail specimens collected were preserved, all specimens 
possible were collected. The Porto Volho MZUSP expedition did not have a herpetologist along, and Mittermeier purchased frogs from local children, a proven technique for lizards (e.g. Vanzolini, 1974).

One practical question to raise is whether the purchase technique is an effective way to sample the frog fauna of Amazonia. A comparison of the Porto Velho - MZUSP and EPA - Mittermeier collections with the Madeira and Purus collections show the former two collections have many more specimens than that of the Purus - Madeira collections; however, the latter two have a greater species diversity. The major discrepancy occurs with the forest associated fauna. Less than $0.01 \%$ of the specimens from the Porto Velho MZUSP collection are forest associated species. No more than $5 \%$ of the EPA Mittermeier specimens are forest associated species; these came from about half of the localities where Mittermeier purchased specimens. If the diurnal forest litter species are excluded, then less than $1 \%$ of the EPA Mittermeier specimens are forest associated species from about one quarter of the localities. The Porto Velho - MZUSP and EPA - Mittermeier collections are mostly represented by open formation associated species. The purchasing technique in Amazonia, thus, is good for large samples of open formation associated species, weak for sampling forest associated species.

The most ccmmon ( $>100$ specimens) randomly collected open formation asscciated species can be analyzed in terms of relative abundance among collecting sites (Table 4). It is immediately obvious that what is common at one site is rare at another. Of the 280 Leptodactylus ocellatus collected, 254 came from a single site, Coari: 125 on 19 September 1973, 129 on 16-17 October 1973. Within a single season, it would appear that common species remain common. Of all the common species, Bufo marinus is the only one to approach a ubiquitous pattern of abundance and distribution.

This phenomenon of local rarity or abundance of species holds true over very small distances. At Borba, one hillside had many forest floor frogs, the hillside opposite a small stream had almost none. At Puruzinho, we transected large areas of forest floor and found one very small area where we collected many more specimens than anywhere else, yet all the forest floor appeared similar.

TABLE 4. Common open habitat associated species in the EPA-Mittermeier collection.

\begin{tabular}{lccc}
\hline Species & Total number & $\begin{array}{c}\text { Greatest number } \\
\text { of specimens } \\
\text { from ony } \\
\text { stingle losotion- } \\
\text { time period }\end{array}$ & $\begin{array}{c}\text { \% } \\
\text { of individualsence } \\
\text { omong cill } \\
\text { localities } \\
\text { sampled }\end{array}$ \\
\hline B. marinus & 209 & 50 & 66 \\
H. geographica & 1205 & 1185 & 8 \\
H. punctata & 218 & 82 & 26 \\
H. rubra & 367 & 219 & 60 \\
L. fuscus & 164 & 146 & 8 \\
L. ocellatus & 280 & 129 & 13 \\
L. limellus & 5046 & 4737 & 18 \\
\hline
\end{tabular}

\section{ANURAN DIVERSTTY}

Two general questions concerning the Hylaean fauna are: (1) Is the fauna uniformly distributed throughout the basin? and (2) Is the Andean Amazonian slope fauna more diverse than the basin fauna?

The Amazonian Andean slope frog fauna is among the most diverse faunas in the world. One site, Santa Cecilia, Ecuador, has been intensively sampled by field parties from the University of Kansas (e.g., Crump, 1974). The total of 81 species of frogs reported from Santa Cecilia is probably close to the true number of species present there. I worked at Limoncocha, Ecuador for two months, making collections of amphibians in the same way the Purus and Madeira collections were made. The known frog faunas of Limoncocha and Santa Cecilia are identifical. Collecting curves were constructed for the Limoncocha, Purus, and Madeira collections, by plotting the number of frog species added per collecting day (Fig. 1). 


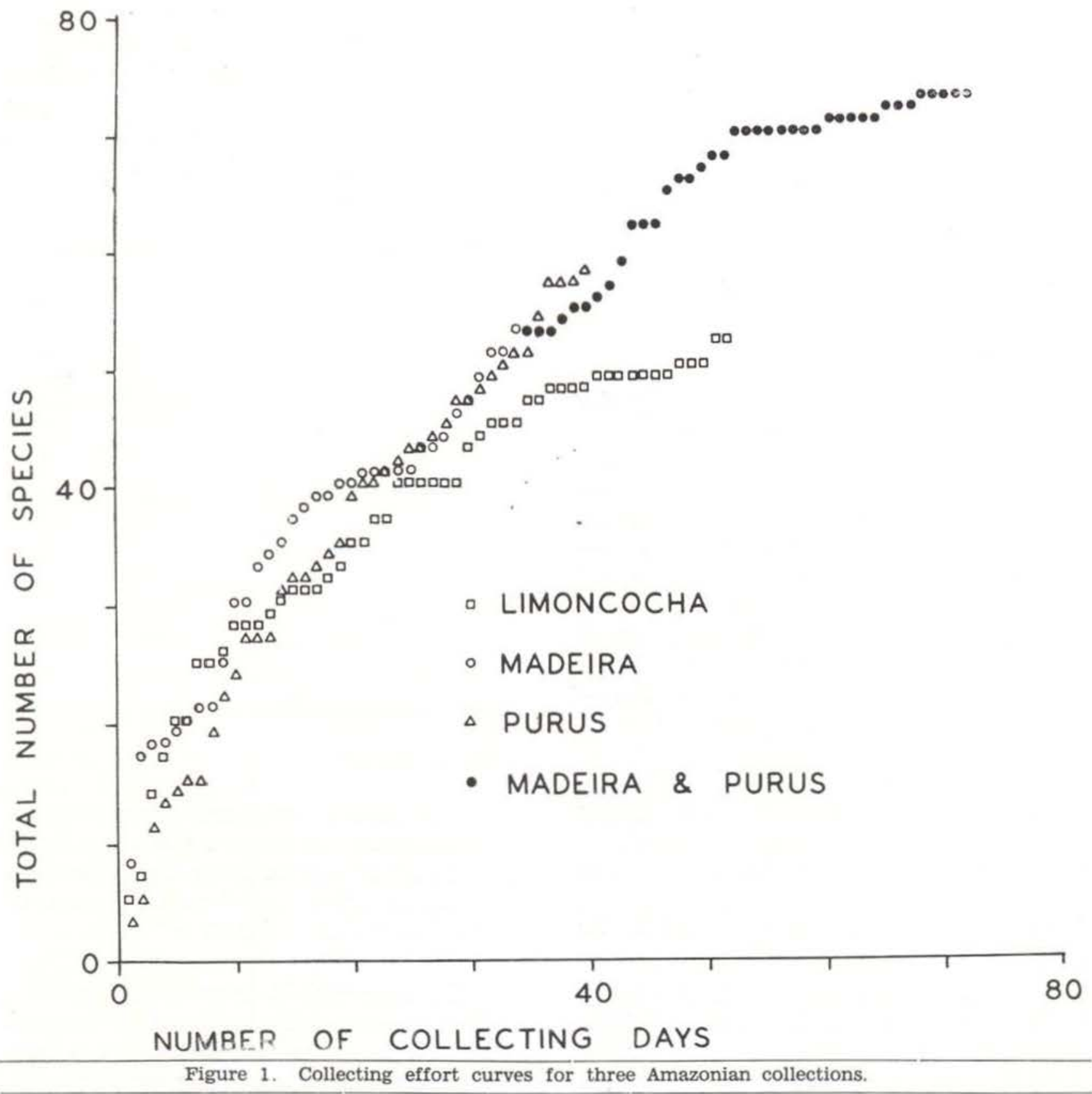

The collecting curves for the Limoncocha, Madeira, and Purus collections all start out similarly, but the Purus and Madeira curves are visibly steeper than the Limoncocha curve, indicating that the Madeira and Purus frog faunas contain more species than the Limoncocha fauna. Many of the species of the Madeira and Purus collections are the same, but there are several species represented in one collection and not the other. Most of these differences are due to seasonal differences in collecting times. The Madeira collection was made in the transition period between the dry and wet season. Species such as Bufo granulosus and Leptodactylus fuscus, which breed at the very beginning of the wet season are well represented in the Madeira collection and absent in the Purus collections. Alternatively, several forest breeding hylids are represented in the Purus collections that are not present in the Madeira collections. The Madeira and Purus collections, back to back, span the transition from dry season to wet season; the greatest period of anuran breeding 
TABLE 5. Preston canonical estimates (see text).

\begin{tabular}{|c|c|c|}
\hline Collections & $\begin{array}{l}\text { Number of } \\
\text { species in } \\
\text { collection }\end{array}$ & $\begin{array}{c}\text { Predicted } \\
\text { number of } \\
\text { species in } \\
\text { founa }\end{array}$ \\
\hline Limoncocha............ & 52 & 72 \\
\hline Purus $\ldots \ldots \ldots \ldots \ldots \ldots$ & 58 & 87 \\
\hline 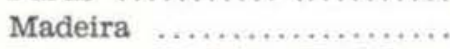 & 53 & 98 \\
\hline $\begin{array}{l}\text { Purus + Madeira }(\mathrm{P}+\mathrm{M}) \ldots \\
\text { Porto Velho-MZUSP, }\end{array}$ & 73 & 118 \\
\hline $\begin{array}{l}\text { EPA-Mittermeier, } \mathrm{P}+\mathrm{M}, \mathrm{A} \text {. } \\
\text { Porto Velho-MZUSP, }\end{array}$ & 81 & 150 \\
\hline EPA-Mittermeier, $\mathrm{P}+\mathrm{M}, \mathrm{B}$. & 81 & 109 \\
\hline
\end{tabular}

activity. The Purus collection data, added to the Madeira data, forms a smooth coilecting curve (Fig. 1) also indicating the two samples are from the same fauna. There is also the first indication of a leveling off at the end of this combined curve.

Preston (1962) proposed a formula for predicting the actual number of species based on a random sample of the fauna. As already discussed, the collections are not truly random, so any predictions will be approximate at best. The Preston canonical estimate is:

$$
\mathrm{N}=\mathrm{y}, 6 \sqrt{2 \pi} \text {, where }
$$

$\mathrm{N}=$ the predicted number of species, $\delta=\log$ standard deviation (Preston, 1962, p. 203 provides a table for this value based on the actual number of species in the collection), and $y_{0}=$ the number of species in the modal octave, where the octaves are set up by ranking the numbers of individuals of each species collected. The estimated results for the collections are presented in Table 5. The one estimate for which the probable value is known (Limoncocha) is underestimated. The last two values of the table are estimated from combined data of the Porto Velho MZUSP, EPA - Mittermeier, Madeira and Purus collections. The first estimate is using the modal octave, which in this case is the first octave, containing species represented by one or two specimens. The second estimate is based on the octave containing the next highest number of species and is included because it is more consistent with the other estinfates.

At the moment, it would appear that a reasonable estimate of the number of species in the Hylaean frog fauna is at least 100. This is higher than the diversity at Santa Cecilia, but the geographic extent of the Hylaea is obviously much greater than Santa Cecilia. As is clear from Figure 1, collecting data for at least 40 days are needed from a single site in the basin proper to determine whether the diversity at a basin site is comparable to the slope fauna diversity.

\section{ZOOGEOGRAPHY}

The anuran fauna at Santa Cecilia is to date the most diverse studied Crump, (1974). Recent revisionary studies have suggested that certain species have distributions associated with the upper Amazon basin of Colombia, Ecuador and Peru (e.g. Duellman, 1973, 1974a, b, Duellman and Crump, 1974). Groups of species with such distribution patterns would add to the overall diversity of the upper Amazon basin, contrasting with the presumed lower diversity of the lowland Amazon basin.

The four collections reported here are from the western half of the Brasilian Amazonian lowlands. Duellman and his associates (Duellman, 1973, 1974a, b, Duellman and Crump, 1974) have recently published studies based on previously available museum materials. In those studies, the following species were not known from the lowland Amazon basin and characterized as having upper Amazon distribution patterns: Hyla fasciata, H. parviceps, H. sarayacuensis, Phyllomedusa palliata, P. tarsius, and Sphaenorhynchus carneus. All of these species are represented in the collections from the western half of the Brasilian Amazonian lowlands. It is obviously premature to characterize individual distribution patterns as upper Amazonian. However, when one compares the total species lists of Santa Cecilia against the 4 coilections of this report, the differences are appreciable. About $49 \%$ of the species recorded from Santa Cecilia are not found in the lowiand Amazon collections. About $45 \%$ of the species in the lowland Amazon collections are not recorded from Santa Cecilia. Some of these differences are accounted for by differences in taxonomic opinion. These amount to no more than $7 \%$ 
of the observed differences. Some of the species recorded from Santa Cecilia are known previously from the lowland Amazon basin. These account for at least $6 \%$ of the differences with respect to the Santa Cecilia fauna. For one group, the centrolenids, I am confident they are not present in the lowland A.mazon basin due to lack of proper breeding habitat. The centrolenids comprise $3 \%$ of the Santa Cecilia frog fauna. There are no other obvious habitat differences that would explain faunal differences between the upper and iowland portions of the Amazon basin. Thus, $33 \%$ of the faunal differences observed can not be readily explained at present. Sampling error certainly is contributing to this figure, but the degree is unknown. At this point, the available data suggest the following zoogeographic conclusions: (1) Any zoogeographic faunal analysis is premature at present due to imperfect sampling of the Amazonian frog fauna; but (2) It appears that the upper Amazon slope fauna differs in degree from the lowland Amazon frog fauna. Precisely how and why the faunas differ is unanswerable with the present data base.

Another apparent difference between the slope and the lowland basin faunas involves a combination of population densities and microhabitat usage. I wanted to gather comparative data along the Purus on the tree buttress herpetofauna to compare with the Limoncocha tree butress herpetofauna (Heyer and Berven, 1973). On the third working day of the Purus expedition, I worked several of the kinds of buttresses which almost always had animals at Limoncocha. Enough buttresses were sampled that a similar search at Limoncocha would always yield specimens. No amphibians or reptiles were found in the tree buttresses along the Purus.

It is difficult to interpret distributional differences between the Madeira and Purus collections owing to the seasonal differences between the collections. The following, based more on impression than on data, is offered as a hypothesis. The Madeira river system appears to have a greater role in fauna! exchange than the Purus river. That is, supposed Bolivian elements of the fauna penetrate much further along the Madeira toward the Amazon River than along the Purus, and open formation species which apparently followed open habitats from the mouth of the Amazon inland, penetrate much closer to Bolivia along the Madeira than the Purus.

\section{SPECUlative CONCLUSIONS}

The role of competition in the organization and structure of tropical wet forest communities has received considerable attention. Current views range from a community characterized by competition to a competition free community. Data bearing on the question are precious few and generally inconclusive. Unfortunately, no direct evidence was gathered on the expeditions reported here. Two circumstantial pieces of evidence argue (rather convincingly, to me) that interspecific competition is negligible within the wet tropical forests sampled. The first argument is that the distribution of each species is a patchwork of locally common and locally rare populations. Thus any competition that occurs is a local phenomenon, probably for one season, with interspecific interactions changing from one year to the next. Even though natural selection can operate with a small rate of population gene frequency change, the rate must be consistent to be effective. It is difficult to envision a constant level of interspecific competition for any Amazonian species over any significant portion of its range. The second argument is that the densities of even the common forest species are very low. These data on forest species are important because the captures in the forest represent largely nonbreeding individuals. Thus, frogs collected in the forest should reflect potential competition for food and space unrelated to breeding site competition. The average capture rate of forest frogs at night was approximately 1.5 frogs/person/ hour. The average capture rate of forest floor frogs in the daytime was approximately 2.3 frogs/person/hour. It is difficult to envision competition occurring among animals with such apparently low densities.

The frog diversity of the Amazon basin is high, and the diversity at any given place in 
the basin proper probably approaches the diversity recorded at Santa Cecilia, Ecuador. Not all species appear to be distributed throughout the Amazon basin, but many more collections will have to be made before negative evidence can be trusted. One pastime all workers who have been overwhelmed by the Hylaean fauna have indulged in is trying to explain the origin of the faunal diversity. The following speciation models seem to be involved in the history of the Hylaean frog fauha. The degree to which each is involved is totally unknown at present. The importance of each model in explaining the total diversity will provide a fruitful challenge for future work on the Hylaean frog fauna. I believe any synthesis will have to take into account the basic dichotomy of forest vs. open formation associated species and diurnal vs. nocturnal forest species.

Refugia model. Ever since the pioneer work of Haffer (1969) and Vanzolini and Williams (1970) the refugia model has been used to explain many patterns in specific groups, not always correctly (e.g. Heyer, 1973 for Adenomera hylaedactyla). As shown by Vanzolini and Williams (1970), the model can account for some of the diversity of the forest associated species faunal segment in Amazonia.

Open formation model A. Some species presently associated with open formations had their evolutionary origin in open formations outside the Hylaea and subsequently invaded the open formations of the Hylaea. Leptodactylus fuscus seems a likely candidate for this model.

Open formation model B. Other species presently associated with open formations had their evolutionary origin in the Hylaean open formations. Adenomera hylaedactyla is an example of this model (present habitat information superimposed on Heyer, 1973).

Vicariant speciation model. This model is the least understood with respect to mechanism, but the result is species distributions that appear to replace each other. This model may"acutally be involved in the refugial model, where species distributions replace each other geographically, not ecologically, and in the open formation model B where species may replace each other ecologically. An example of the latter is the forest associated species Adenomera andreae and its close relative, the open formation associated Adenomera hylaedactyla. I find it interesting, but presently unexplainable, that one of these is diurnal (A. andreae), the other nocturnal.

Hylaean-Atlantic forest faunal interchange model. Species that evolved in one of these wet forest units subsequently invaded the other. This model is included as a possible conjecture at this point. Much of the Atlantic forest fauna is distinct from the Hylaean frog fauna, vice versa. The present taxonomic knowledge of the most promising groups that would exemplify this pattern, the bufonids and hylids, is so poor that nothing can be said either in support of the model or against it.

\section{ACKNOWLEDGMENTS}

Dr. Paulo E. Vanzolini kindly invited me to join him on the Purus and Madeira expeditions. The expeditions were most profitable and enjoyable under Dr. Vanzolini's careful guidance. My insights on the nature of the Amazonian fauna are due to Vanzolini's constant and unselfish sharing of his more than 20 years experience.

Without the help of the following friends who joined in the field work, the co!lections would be considerably less important: Carlos Roberto F. Brandãc, Miriam Heyer, Francisca Carolina do Val, P. E. Vanzolini.

The manuscript has been carefully read by P. E. Vanzolini and G. R. Zug.

My participation was supported by MZUSP and the Smithsonian Research Foundation. This is a contribution of the Amazon Ecosystem Research Program (Smithsonian Institution).

\section{Resumo}

Apresenta-se informaçăo biológica derivada do estudo de 4 coleçôes grandes de anuros, feitas na bacia amazônica. A maior parte das espécies está associada a determinados subconjuntos ambientais associados a formaçốes abertas ou a florestas, mas não a ambos os tipos simultaneamente. Todos os anuros diurnos são espécies do folhiço do chăo da mata; todas as espécies de formaçōes abertas sāo noturnas. 
Há, entre as coleções de água das formações abertas, poucas associações positivas de pares de espécies em reproduçāo, o que indica que a fauna de anuros de formaçōes abertas nâo tem uma estrutura comunitária estreitamente integrada. Quase todas as espécies se reproduzem fora dos rios maiores; apenas duas espécies possivelmente se reproduzam no leito principal dos rios. As espécies encontradas na floresta à noite, sobre folhas, estão aparentemente à caça de insetos.

Na Amazônia, a técnica de comprar exemplares de crianças fornece amostras grandes de espécies associadas a formaçōes abertas, mas poucas espécies associadas à floresta. As espécies são caracterizadas por estruturas populacionais de abundância e de raridade locais. Isto é verdade em termos de distâncias geográficas desde grandes até muito pequenas.

A fauna de anuros da hiléia contém pelo menos 100 espécies. Uma análise zoogeográfica seria atualmente prematura, pois a amostragem faunística é incompleta, mas quer parecer que a fauna das encostas orientais andinas difere em qualidade da fauna da planície. Provas circunstanciais militam contra a hipótese de que a competição interes pecífica seja importante nas florestas úmidas pesquisadas

Cinco modelos de especiação podem ser invocados para explicar a alta diversidade da fauna de anuros da hiléia.

1) Modelo de refúgios. Este modelo, explicado por Vanzolini \& Williams (1970), explica parte da diversidade das espécies associadas a florestas;

2) Formações abertas, modelo A. Algumas espécies atualmente associadas a formações abertas tiveram sua origem evolutiva em formações abertas fora da hiléia e subseqüentemente invadiram as formações abertas da hiléia;

3) Formaçôes abertas, modelo B. Outras espécies atualmente associadas com formações abertas tiveram sua origem nas formações abertas da hiléia;

4) Modelo de especiação vicariante. Este modelo ainda nâo está bem elucidado no que diz respeito a mecanismos, mas o resultado são distribuições de espécies que parecem substituir-se geográfica ou ecologicamente;

5) Modelo de permuta entre hiléia e mata atlântica. Espécies que evoluiram em uma dessas florestas úmidas subsequientemente invadirom a outra.

\section{LITERATURE CITED}

Collins, J.P.

1975 - A comparative study of the life history strategies in a community of frogs. ix +148 pages. Unpublished $\mathrm{Ph}$. D. Dissertation, University of Michigan.
CRUMP, M.L.

1974 - Reproductive strategies in a tropical anuran community. University of Kansas Museum of Natural History Miscellaneous Publications, 61:1-68.

Duellman, W.E.

1973 - Frogs of the Hyla geographica group. Copeia, $1973: 515-533$.

1974 a - A reassessment of the taxonomic status of some neotropical hylid frogs. Occa. sional Papers of the Museum of Natural History, University of Kansas, $27: 1-27$.

1974b-Taxonomic notes on Phyllomedusa (Anura: Hylidae) from the upper Amazon basin. Herpetologica, 30 : 105-112.

Duellman, W.E. \& CRUmp, M.L.

1974 - Speciation in frogs of the Hyla parviceps group in the upper Amazon basin. Occasional Papers of the Museum of Natural History, University of Kansas, $23: 1-40$.

HAFFER, J.

1969 - Speciation in Amazonian forest birds. Science, $165: 131-137$.

HEYER, W.R.

1973 - Systematics of the Marmoratus group of the frog genus Leptodactylus (Amphibia, Leptodactylidae). Contributions in Science, Natural History Museum, Los Angeles County, 251:1-50.

1976 - Studies in larval amphibian habitat partitioning. Smithsonian Contributions to Zoology, in press.

HEYER, W.R. \& BERVEN, K.A.

1973 - Species diversities of herpetofaunal samples from similar microhabitats at two tropical sites. Ecology, 54:642-645.

HEYER, W.R.; MCDIARMid, R.W. \& WeIGMANN, D.L.

1975 - Tadpoles, predation and pond habitats in the tropies. Biotropica, $7: 100-111$.

PIELOU, E.C.

1969 - An Introduction to Mathematical Ecology. New York. Wiley-Interscience, viii +286 pages.

PrEston, F.W

1962 - The canonical distribution of commonness and rarity. I. Ecology, 43:185-215.

VANZOLINI, P.E.

1974 - Ecological and geographical distribution of lizards in Pernambuco, northeastern Brasil (Sauria). Papéis Avulsos de Zoologia, São Paulo, 28 : 61-90.

VANZolini, P.E. \& Williams, E.E.

1970 - South American anoles: The geographic differentiation and evolution of the Anolis chrysolepis species group (Sauria, Iguanidae). Arquivos de Zoologia, São Paulo, 19:1-298. 